\title{
台風強大化に伴い砂浜海岸で想定される 地形変化と底質粒径変化に関する検討
}

\section{Sandy beach changes by global warming on the analogy of changes of beach profile and sediment grain size caused by powerful storm}

\author{
柳嶋慎 ${ }^{1}$
}

\section{Shin-ichi YANAGISHIMA}

\begin{abstract}
Based on the observed data for 27 years from 1986 at Hazaki Oceanographical Research Station, the changes of crossshore profile and the mean sediment diameter at beach surface by huge storms have been extracted. As results, the longshore bar disappears by storm and high waves come to reach the shore. Therefore, the newly formed bar comes to be eroded easily and fine sand cannot stay near the shoreline. On the assumption that the storm is made huge by global warming, it is expected that the former beach slope becomes steep and the grain diameter near the shoreline roughens.
\end{abstract}

\section{1.はじめに}

砂浜は，地球全体の中で不可欠な生態系を形成する場 所であるとともに，高潮・津波など海域由来の自然災害 に対する緩衝地帯となることにより，防災・減災機能を 発揮すると，磯部（2013）は，述べている.

日本有数のはまぐりの生産地である鹿島灘海岸におい て，鹿島灘はまぐり稚貝は，近年減少しており，根本ら （2009）は，砂浜侵食域に打ける汀線付近底質の粗粒化 および沖合のバーの消滅と稚貝の減少との関係を指摘し ている.

一方，地球温暖化にともなう海水面の上昇，台風の強 大化，大きな台風の発生個数の増加により，砂浜の消失 が想定されており（国土交通省，2008），砂浜の維持管 理が求められている.しかしながら，台風の強大化にと もなう砂浜の消失に関する研究は，なされていない．

本研究では, 地球温暖化による台風の強大化にともな い砂浜海岸において想定される，地形および底質粒径の 変化を，波崎海洋研究施設周辺で1986年から2012年に 観測した地形および砂浜表面の底質粒径デー夕を基に検 討した.

\section{2. 調查方法}

調査は，図-1に示す，茨城県神栖市の鹿島灘に面する 波崎海洋研究施設（以後，HORS と呼ぶ）周辺海岸で実 施した，HORSでは，平均汀線付近にある観測栈橋基部 を原点とし，岸沖方向を $y$ 軸（沖方向を+)，沿岸方向を $x$ 軸（銚子方向を + ）とするHORS 固有の座標系を使用 している (図-2参照)。また，高さの基準は，波崎港工

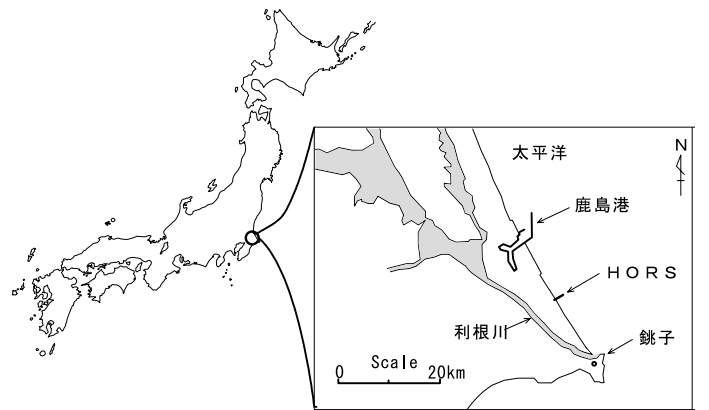

図-1＼cjkstart調査位置図

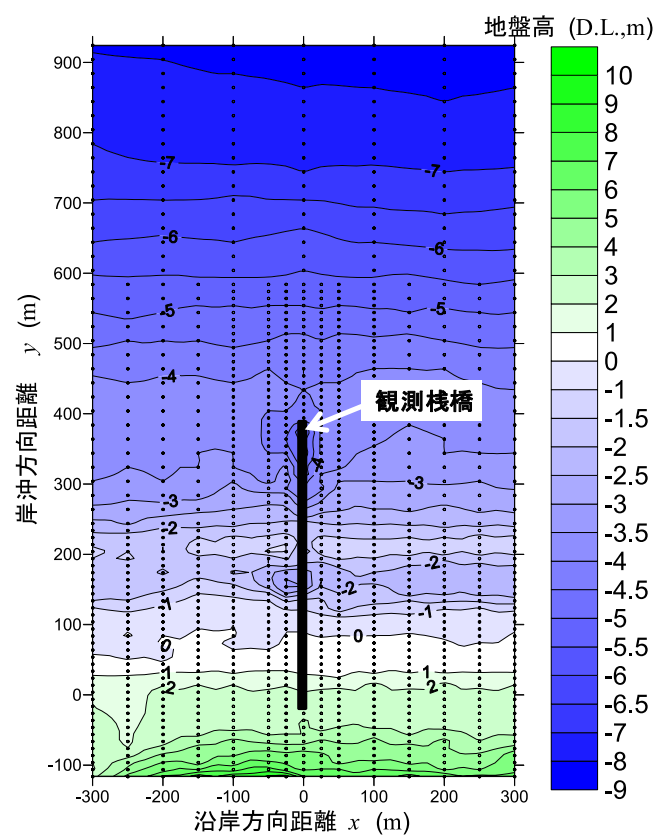

図-2 調查対象地域の地形 （2006年 8 月測量，・印は測量地点を示す） 
事基準面（D.L.0m=T.P.-0.687m）を使用している.

観測栈橋に沿う断面地形は，1986年3月12日から 2012 年 10 月 2 日まで, 岸沖方向間隔 $5 \mathrm{~m}$ で, レベル・スタッフ を用い測量した（101地点，6434回）.

広域の地形を把握するために，深浅測量を2006年 8 月 と2007年 8 月に，図-2に示す範囲について実施した。

海底部の表面底質は，1987年6月には，スミスマッキ ンタイヤー式採泥器を用い, 岸沖方向間隔 $10 \mathrm{~m}$ で（詳細 は加藤ら 1990 参照)，2010年7月には潜水し，岸沖方向 間隔 $40 \sim 55 \mathrm{~m}$ で, 表面から深さ $5 \mathrm{~cm}$ までの砂を直接採取 した。陸上部の表面底質は，1987年，2010年 8 月とも岸 沖方向間隔 $10 \mathrm{~m}$ で, 砂浜表面から深さ $3 \mathrm{~cm}$ までの砂を直 接採取した。

粒度分析は, 試料を水洗い乾燥後, 1987年には, ふる い振とう器を用い，2010年には，自動砂フルイ装置（ロ ボットシフターRPS-205）によって行った. 分析の際の

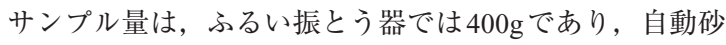
フルイ装置では約 $12 \mathrm{~g}$ である.

\section{3. バーの消滅}

断面地形変化の概要を把握するために，1986年 3 月 12 日から 2012年10月 2 日までの間のデー夕（6434回）を用 い, 経験的固有関数解析（例えば, 加藤ら，1981）を行 った。

経験的固有関数を用いると, 地盤高は次式で表される.

$$
h(y, t)=\sum_{n} c_{n}(t) \cdot e_{n}(y)
$$

ここで, $h(y, t)$ は測点ごとの平均地盤高からの変化量で あり平均地盤高よりも高い場合を正としている，yは岸 沖方向距離, $t$ は時間, $c_{n}(t)$ は, モード $n$ の時間係数, $e_{n}(y)$ は, モード $n$ の固有関数である.

図-3 は, 解析対象期間の平均断面を黒実線で, モード 1 (寄与率 $28 \%)$, モード2（寄与率 $24 \% ）$ の固有関数 $e_{1}$, $e_{2}$ の岸沖分布を青線, 緑線で示している.

固有関数の值は, $e_{1}, e_{2}$ とも, 岸沖方向距離 $y=160 \mathrm{~m} \sim$ $350 \mathrm{~m}$ の間で大きく, かつ両者の位相がずれおり, 波崎海 岸の地形変化は, 栗山（2001）が述べたバーの発達・移 動が特徵的であることが分かる.

図-4は, 時間係数 $c_{1}, c_{2}$ の経年変化を示している. 時 間係数の值は, $c_{1}, c_{2}$ とも，図中に赤線で示す 2006 年 10 月 6 日までは, 1 年〜数年周期で 0 を中心に変動しており, バーが周期的に移動していることが分かる．ところが， 鹿島灘に高潮をともなう異常波浪が来襲した 10 月 7 日以 降， $c_{1}, c_{2}$ とも周期的な変動は見られるものの, 值は正 の範囲で変化している.つまり, $y=200 \mathrm{~m} よ り も$ 沖側のバ 一は，平均断面よりも低い範囲で変動するようになった ことを示している.

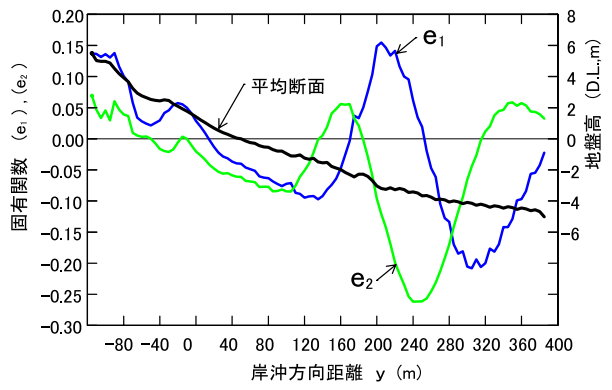

図-3 平均断面および固有関数の岸沖分布（1986～2012年）

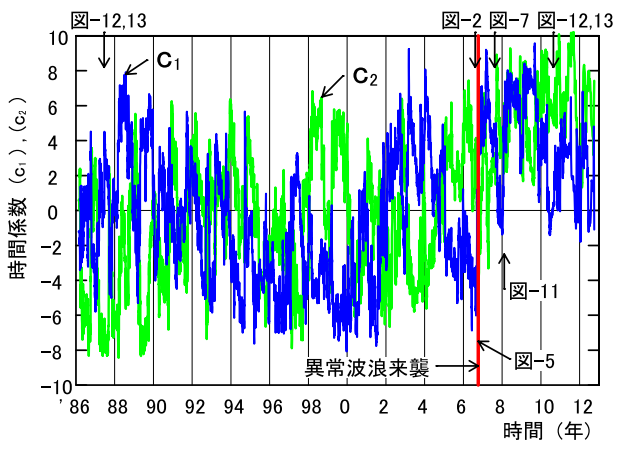

図-4 時間係数 $c_{1}, c_{2}$ の経年変化

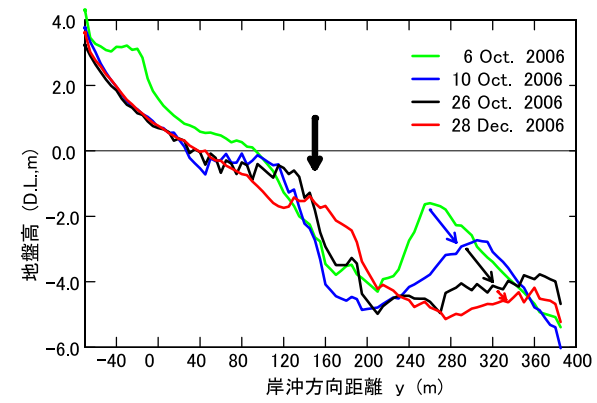

図-5 異常波浪来襲前後の断面地形変化

柳嶋（2012）によれば, この時常陸那珂港において, 有義波高 $7.59 \mathrm{~m}$, 有義波周期 $10.4 \mathrm{~s}$ （常陸那珂港の既往最 大を更新）が観測されており，欠測していた鹿島港の波 浪を, 常陸那珂港の波浪から, 加藤ら（1989）にならっ て推定すると, 有義波高 $8.9 \mathrm{~m}$, 有義波周期 $11.3 \mathrm{~s}$ を得る. 鹿島港の既往最大は, 有義波高 $7.5 \mathrm{~m}$, 有義波周期 $10.5 \mathrm{~s}$ （清水ら 2007）であり, この時の波高は, 既往最大より も $1.4 \mathrm{~m}$ 高くなっていた. 更に, もう一つの特徵は, 周期 が長く（10s 以上で最大 $13.8 \mathrm{~s} ）$ 波高が $5 \mathrm{~m}$ を越える波が 32 時間余り継続したことである。

図-5は，異常波浪が来襲した前後の断面地形を示して

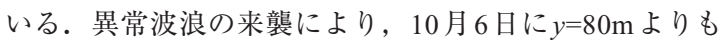
陸側に存在したバームが完全に侵食されるとともに, $y=260 \mathrm{~m}$ 付近にあったバーが沖に移動・減衰した.その後, 
10 月 24 日の低気圧の通過（有義波高 $7.0 \mathrm{~m}$, 周期 $11.2 \mathrm{~s}$ ) に伴いバーはさらに沖に移動・減衰し，12月27日の低気 圧の通過（有義波高 $5.1 \mathrm{~m} ，$ 周期 $11.4 \mathrm{~s}$ ）によって，バーは 完全に消滅している。この時，栗山（2001）が明らかに した，バーの減衰過程で生ずる岸向き漂砂による， $y=150 \mathrm{~m}$ （太黒矢印）付近への砂の堆積は生じなかった.

図-6は，D.L.0mよりも高い範囲（陸上部）と低い範囲 （海中部）に分け，1986年3月12日を基準とし，それぞ れの断面土量の変化を示したものである．陸上部の土量 は，台風もしくは低気圧通過時にバームが侵食されるた め, 一時的に減少傾向を示すが，バームが再び形成され る事と, 波崎海岸の卓越風である北寄りの風によって, 汀線付近の砂が後浜に運ばれ，堆積するため，年々増加 傾向にある．図中，赤線で示す異常波浪来襲時に土量は 大きく減少するが，その後急激に回復し，増加の一途を たどっている.

一方, 海中部の土量は, 異常波浪が来襲するまでの間, ほぼプラス側で変動（平均 $+198 \mathrm{~m}^{3} ）$ しているが，来襲後 はマイナス側に転じ (平均 $-63 \mathrm{~m}^{3}$ ), 約 $260 \mathrm{~m}^{3}$ の砂が失わ れたことになる，つまり，バーを形成していた砂は，異 常波浪とその後連続した低気圧によって観測栈橋よりも 水深の深い沖に移動したものと考えられる.

この時の砂の広い範囲での移動を検討するために，異 常波浪来襲前後の深浅測量結果を比較した。

図-2に示した異常波浪来襲 2 ケ月前の 2006 年 8 月の地 形図において, $y=200 \mathrm{~m}$ 付近に存在するバーを含め, $-7 \mathrm{~m}$ までの等深線は, 海岸線とほぼ平行になっている。なお, $y=200 \mathrm{~m}$ 付近に存在するバーは，2006年9月 1 日〜 8 日の 荒天の間に，図-5に示す $y=260 \mathrm{~m}$ 付近に移動した。

図-7は，異常波浪来襲から 10 ケ月経過した 2007 年 8 月 の地形測量結果を示している。バーよりも沖側の- $6 \mathrm{~m}$ か ら-7.5mの等深線は， $x=-300 \mathrm{~m}$ および $0 \mathrm{~m}$ 付近で陸側に凹 み, $x=-200 \mathrm{~m}$ 付近で逆に沖に張り出しており, 図-2に示 した 2006 年 8 月のほぼ直線的な形状とは，大きく異なっ ている.

図-8は，2006年 8 月から 2007年 8 月までの間の地盤高 変化量の空間分布を示している。図-5に示したとおり, バームの存在した $y=0 \mathrm{~m} \sim 80 \mathrm{~m}$ およびバーの存在した $y=200 \mathrm{~m} \sim 300 \mathrm{~m}$ 付近の地盤高の低下量が多くなっている (侵食).ささらに, 観測栈橋よりも沖側の $y=400 \mathrm{~m} \sim 700 \mathrm{~m}$ の範囲（図-2から，-4m〜-6.5mの等深線に相当）の地盤 高は低下し,$y=700 \mathrm{~m} よ り も$ 沖側の地盤高は高く（堆積） なっている.

以上の結果から，異常波浪により，バーが存在した位 置から-6.5mの等深線までの広い範囲で侵食が生じ，この 範囲の砂は, さらに深い沖合へ移動したことが分かる.

過去の深浅測量結果を調べたところ，深い範囲まで侵

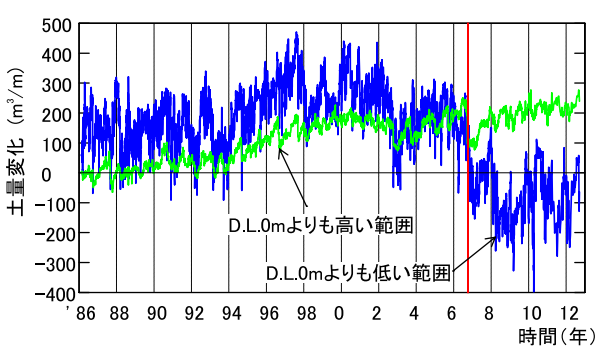

図-6＼cjkstart観測栈橋に沿う断面の土量変化

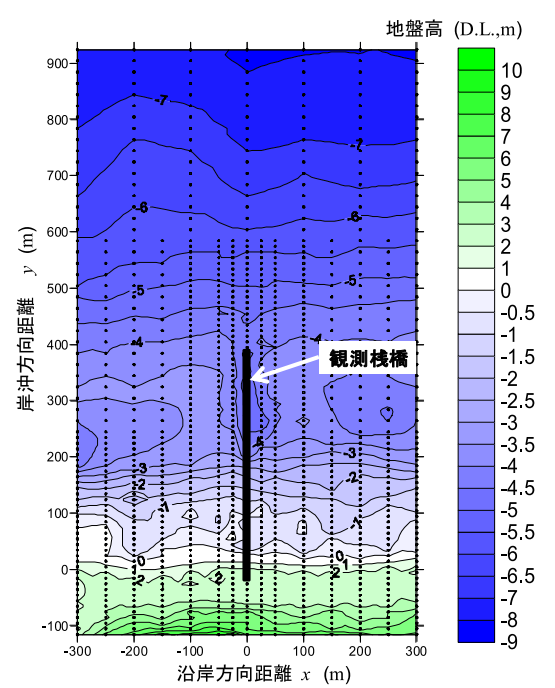

図-7 異常波浪来襲後の平面地形（2007年8月測量）

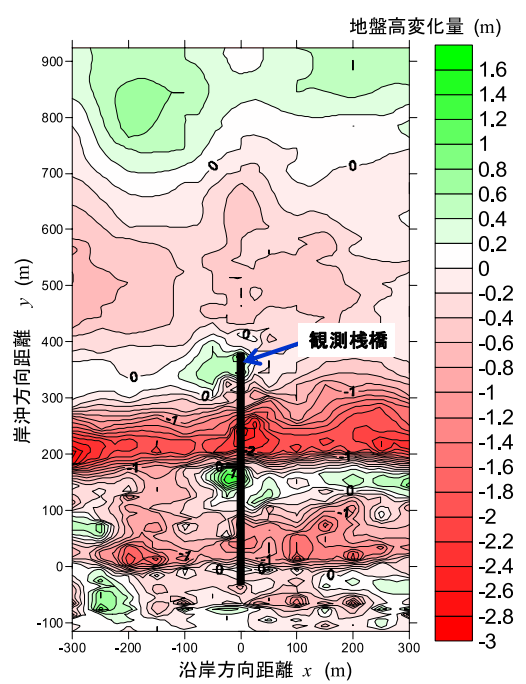

図-8 異常波浪来襲前後の地盤高変化量の空間分布 (2006年 8 月-2007年 8 月)

食が生じたのは，2002年 8 月から 2003 年 7 月の間 $(-3 \mathrm{~m}$ 〜 -5mの等深線の範囲) だけであった。

根本ら（2009）が指摘した鹿島港北側海岸のバーの消 
滅は, ここに示したような機構で, 生じたものと考えら れる。

バーを含め通常はほとんど変化することのない哚い範 囲まで侵食が生じたのは，2006年10月の波浪が異常に大 きかったためであり，これらの現象が，地球温暖化に伴 い想定される砂浜海岸における变化の一つと考えられる.

\section{4. 浅海域の地形変化}

次に, 異常波浪来襲後の地形変化を経験的固有関数法 により詳しく調べる。解析に用いた断面デー夕は，2006 年 10 月 10 日から 2012 年 10 月 2 日までの間の 1149 回分で ある。

図-9は, 解析対象期間の平均断面を黒実線で，モード 1 (寄与率 $35 \%)$, モード3（寄与率 $12 \%$ ）の固有関数 $e_{1}$, $e_{3}$ の岸沖分布を青線，赤線で示している.

図-3に示した，1986年から2012年までの平均断面形状 と異なるのは, D.L. $0 \mathrm{~m}$ 付近の前浜勾配が急になり, $y=280 \mathrm{~m}$ 付近の地形が下側に凸になっている形状である.

モード 1 の固有関数は， $y=220 \mathrm{~m}$ 付近に正のピークがあ り，図-3に示した，全期間のモード1のピークと同様で ある。しかし，同図において $y=310 \mathrm{~m}$ 付近に存在した負 のピークは，図-9に打いて無くなっており，異常波浪来 襲後，この位置にバーが形成されなくなったことを示し ている.

1986年から 2012年までの断面デー夕による解析では抽 出できなかったモード3の固有関数は, $y=20 \mathrm{~m}, y=180 \mathrm{~m}$ に負のピークがあり, 関数值のほとんどは負の值である.

図-10は，モード3の時間係数の経年変化を示している. 時間係数は，2008年の始まで 0 を中心変動しているが, それ以降， 0 付近からプラス側へ急激に変化しその後ゆ っくり0付近へ戻る変動を繰り返している.

モード3の固有関数がほとんど負の值であること，時 間係数の変化を併せ考えると, $y=0 \mathrm{~m}$ から $y=240 \mathrm{~m}$ の範囲 の地盤高は, 大きな波浪が来襲した時に急激に低下（侵 食）し，その後波が穏やかになるとゆっくり高くなる (堆積)ことを繰り返しているものと考えられる.

図-11 は, 図-10に矢印で示した時の断面変化事例を示 している．2008年2月 4日の断面（緑線）には， $y=140 \mathrm{~m}$ 付近に小規模なバーが，その陸側にトラフが形成されて いる. しかし，有義波高2３.6m，周期 $8 \sim 11 \mathrm{~s}$ の波が継 続した4 日後の 8 日 (青線)には，バーが消滅するとと もにその沖側に砂が移動している。 そして，2月8日以降 も荒天が続き，有義波高 $5.2 \mathrm{~m}$ ，周期 $10.3 \mathrm{~s}$ の波が来襲し た後の 2 月 13 日（赤線）には，干潮時汀線付近が侵食さ れ，前浜勾配は急になっている。この期間， $y=240 \mathrm{~m}$ より 沖側にバーは存在せず，フラットな形状になっている.

その後も, 穏やかな状況が継続すると, 前浜勾配は緩

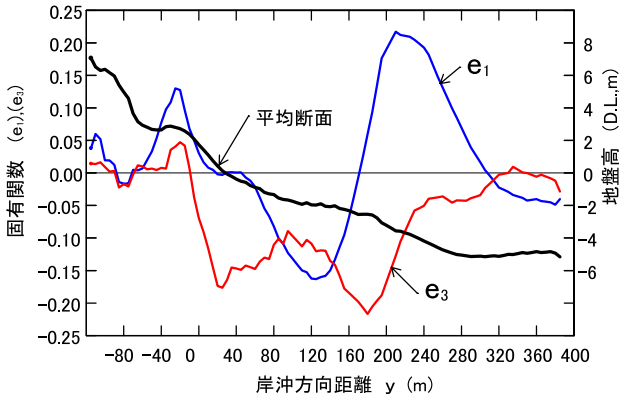

図-9 平均断面及び固有関数の岸沖分布 (2006年 10 月7日以降)

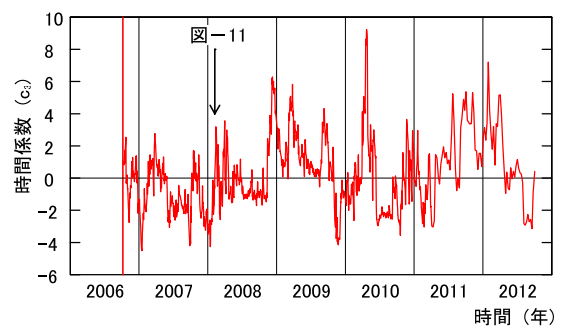

図-10 時間係数（モード3）の経年変化

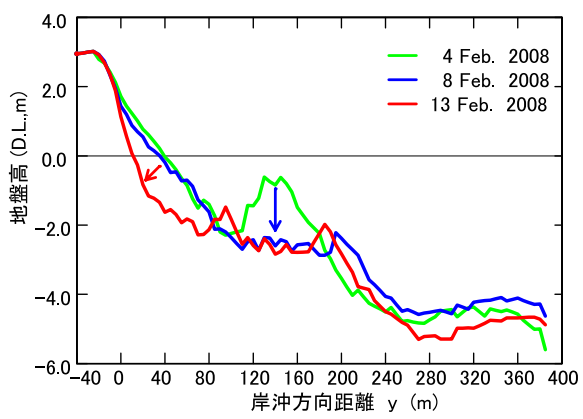

図-11 浅海部の断面地形変化事例（2008年2月）

くなり，小規模なバーも $y=140 \mathrm{~m}$ 付近に再び形成される けれど，波が大きくなると直ぐにバーは消滅するととも に前浜勾配も急になった。

浅海域において侵食が頻繁に生じるのは，図-5におい て, $y=260 \mathrm{~m}$ 付近に存在したバーが消滅したため, 波が減 衰することなく汀線付近まで到達するためと考えられる.

\section{5. 干潮時汀線よりも陸側の底質の粗粒化}

図-12 は，異常波浪来襲前の地形である 1987年6月 17 日と, 異常波浪来襲後の地形である 2010 年 8 月 24 日の断 面地形を示している.

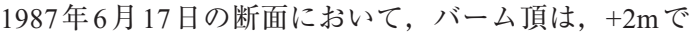
あり, $y=0 \mathrm{~m}$ 付近のバーム斜面の勾配は急であるものの, $y=40 \mathrm{~m} \sim 80 \mathrm{~m}$ の間の前浜の勾配は緩くなっている。 そし て, $y=210 \mathrm{~m}$ 付近にトラフ (水深 $-5 \mathrm{~m}$ ) が, $y=300 \mathrm{~m}$ 付近に 明瞭なバー（頂部水深- $2.5 \mathrm{~m} ）$ が存在している. 


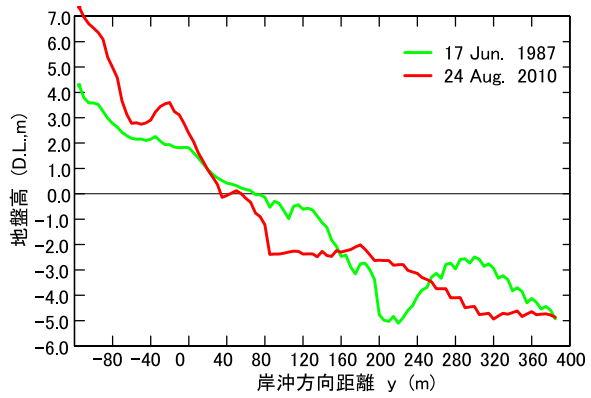

図-12 断面地形の比較（1987年，2010年）

一方，2010年 8 月 24 日の断面において，バームは高く なり，バーム頂からD.L.-2.5mまで $(y=-20 \mathrm{~m} \sim 80 \mathrm{~m})$ 急 な一様勾配の形状になっている。 そして，バーは存在し ない.

図-13は，図-12に対応した1987年6月17日と，2010年 8月24日の砂浜表面の底質中央粒径の岸沖分布を示して いる。なお，2010年の海中部の底質粒径デー夕は，7月 20 日に採取した結果であるが，7月20日から 8 月 24 日の 間，波は穏やかであり，この間に，海中部の断面地形が 変化しなかったことを確認している.

異常波浪来襲前の底質の中央粒径は，トラフの位置に 相当する $y=230 \mathrm{~m}$ 付近で $0.5 \mathrm{~mm}$ と大きくなっている。 そ の他の地点の中央粒径は, $y=80 \mathrm{~m}$ 付近にピーク $(0.25 \mathrm{~mm})$ を持ち，陸側および海側へ離れるほど，細かくなって いる.

異常波浪来襲後の底質の中央粒径は, $y=130 \mathrm{~m}$ よも沖 側の海中部は，異常波浪来襲前と同様で細かい。しかし， 干潮時汀線よりも陸側の底質の中央粒径は, 最大 $1 \mathrm{~mm} に$ なっており，異常波浪来襲前に比べ大きくなっている.

干潮時汀線よりも高い範囲の底質が粗粒化したのは, 沖のバーの消滅により, 波が砕けることなく進入し, 汀 線付近で巻波砕波し，細かな粒径の砂は留まれずに，粗 い砂のみがバーム上へ運ばれるためと考えられる.

このように，干潮時汀線よりも高い範囲の底質が粗粒 化することが，地球温暖化に伴い想定される砂浜海岸に おける2番目の変化と考えられる。

\section{6. おわりに}

地球温暖化による台風の強大化，大きな台風発生数の 増加にともない砂浜海岸において想定される地形変化, 底質粒径の変化を, 波崎海岸で観測した地形デー夕 （1986～2012年)，底質粒径デー夕を基に検討した。温暖 化により砂浜海岸においては，以下のような変化が生じ る可能性がある.

（1）減衰過程にあるバーが消滅し，バーを形成していた 砂は，沖合に運ばれる．

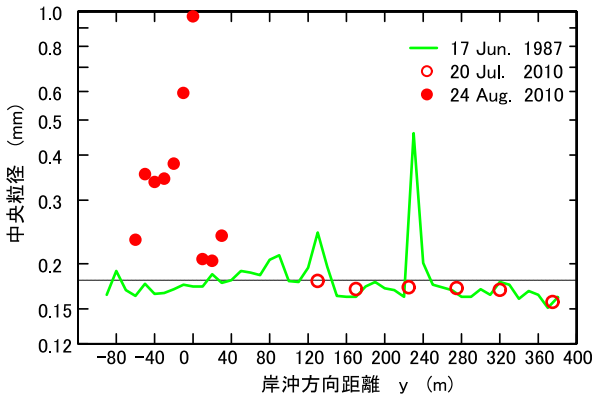

図-13 底質中央粒径の岸沖分布（1987年，2010年）

（2）岸寄りに形成される小規模のバーは容易に侵食され, 汀線付近まで波が到達し, 巻波砕波するため, 細かな 粒径の砂は留まれないため，前浜勾配が急になる。

（3）干潮時汀線よりも高い範囲の底質は, 粗粒化する.

謝辞：本論文の作成にあたり，港湾空港技術研究所上席 研究官中村聡志氏から有益な助言をいただいた．2010年 の海中部の底質サンプルは, 東京大学大気海洋研究所助 教清家弘治氏が採取してくださった．鹿島港㧍よび常陸 那珂港の沖波デー夕は，国土交通省港湾局から提供して いただいた。本解析に用いた断面地形デー夕は，(株) エコー，（株）プライア・コンサルタント，国際気象海 洋（株）の観測補助員の皆様および沿岸土砂管理研究于 ームのメンバーによって観測されたものである。ここに 記し，深謝の意を表する.

\section{参 考 文 献}

磯部雅彦 (2013)：砂浜の機能と現状－海岸の変遷と海岸工学 の展開を踏まえて一，土木学会誌，第 98 卷，第 5 月号， pp.6-9.

加藤一正・田中則男 - 灘岡和夫 (1981)：前浜の二次元的地形 変化と潮位・波について, 第28回海岸工学講演会論文集, pp.207-211.

加藤一正・柳嶋慎一 ·磯上知良・村上裕幸（1989）：波による 汀線付近の水位上昇量一波崎海洋研究施設における現地 観測 - , 港研報告, 第28巻, 第 1 号, pp.3-41.

加藤一正・柳嶋慎一 - 栗山善昭 - 磯上知良・村上裕幸 ・藤田 誠（1990）：砕波帯内の底質粒度の変動特性 - 波崎海洋研 究施設に打ける現地調査一, 港研報告, 第 29 巻, 第 2 号, pp.37-61.

栗山善昭（2001）：沿岸砂州の長期変動特性と底質移動特性, 土木学会論文集, No.677/II-55, pp.115-128.

国土交通省（2008）：平成 19年度国土交通白書，228p.

清水勝義・佐々木誠・永井紀彦（2007）：2006年の台風等によ る高波の観測結果 (NOWPAS2006特別号)，港空研資料， No.1160, 42p.

根本 孝・松浦健郎・仁平 章・岡安章夫（2009）：鹿島灘砂 浜域の地形と底質粒径の経年変化およびそれらがチョウ センハマグリ稚貝の分布に及ほす影響について，水産工 学論文集, Vol.46, No.1, pp.51-64.

柳嶋慎一（2012）：波崎海岸に扔ける大規模な侵食，港空研資 料, No.1256, 21p 